\title{
Current Situation, Problems, and Countermeasures of Enrollment and Recruitment Integration under the Mode of Modern Apprenticeship
}

\author{
Kaitai Hua \\ Hunan Modern Logistic College \\ Changsha, China
}

\begin{abstract}
In order to ensure the efficient implementation of modern apprenticeship around China, it is necessary to accelerate the integration of enrollment and recruitment within the modern academic system. This work closely focused on the integration process of enrollment and recruitment, summed up the current implementation situation of enrollment and recruitment integration and analyzed problems existing in the enrollment and recruitment work, for example, autonomy of enrollment and recruitment pilot units is limited, enthusiasm of enterprises is not high, higher vocational colleges themselves lack understanding of the modern apprenticeship system, and students and parents have some misunderstandings about the modern apprenticeship system. Finally, this work put forward countermeasures based on the perspective of balanced interests among the government, colleges, enterprises and students, providing reference for the modern apprenticeship pilot.
\end{abstract}

Keywords-Modern apprenticeship; Integration of enrollment and recruitment; Current situation; Problem; Countermeasure

\section{INTRODUCTION}

At present, China is in an important period of economic system reform and industrial structure upgrading and transformation, so the demand for technical and skilled talents in all walks of life is becoming increasingly urgent. Especially with the introduction of national development strategies, such as "Internet +", "Made in China 2025" and "Industry 4.0", new occupations and new jobs are emerging rapidly as a result of "three new" economy, which are new industry, new business mode and new pattern. It puts forward higher requirements for technical and skilled talents, and at the same time, this fast-paced skill update poses new challenges for the cultivation of talents. Although higher vocational colleges have reformed traditional methods of training talents and strengthened cooperation with enterprises oriented towards employment, they are still the main body of talent cultivation in essence. Therefore, there is still a certain lag between cultivated talents and market demand, and this phenomenon is particularly obvious. Traditional talent training and market needs do not match and disjoint, which is one of the important reasons leading to a series of problems such as labor shortage, difficult employment and poor employment quality. Therefore, it is imperative to reform the traditional training mode of technical and skilled talents.

In response to the reform of vocational education personnel training mode, many experts and scholars have done a lot of research on this [1-2]. On the one hand, they learn from the training experience of foreign vocational education talents, such as German "dual system", Switzerland "ternary system", America "registered apprenticeship system", Australia "new apprenticeship system" and British "apprenticeship system". On the other hand, they have done a lot of theoretical exploration and research on the localization of foreign vocational education mode based on the actual situation in China, forming theoretical basis for the cultivation mode of Chinese modern apprenticeship talents.

The modern apprenticeship training mode is considered by many experts and scholars as an inevitable choice for the future development of vocational education because of its ability to seamlessly integrate with market needs, improve the quality of personnel training, and broaden the career development of talents. In addition, Chinese government attaches great importance to the development of modern apprenticeship. In the past five years, China has issued a series of documents, such as the Opinions on Promoting the Pilot Work of Modern Apprenticeship System, Decisions on Accelerating the Development of Modern Vocational Education, so as to provide policy support for further exploration and practice of modern apprenticeship.

According to the spirit of the Opinions on Promoting the Pilot Work of Modern Apprenticeship System, four main connotations should be grasped when carrying out pilot work of modern apprenticeship system, i.e., exploring the college-enterprise joint enrollment operation mode of enrollment and recruitment integration, deepening the talent training mode of working while studying, strengthening the construction of dual-mentor faculty which combines full-time and part-time, and exploring the teaching management and operation mechanism that is compatible with the modern apprenticeship system. Among them, the integration of enrollment and recruitment, in essence, is the enrollment work guided by colleges and enterprises, realizing the dual effect of recruiting students equals to recruiting employees and entering the college equals to entering the enterprise. The integration of enrollment and recruitment is an important foundation for the modern apprenticeship pilot project, and it is an indispensable key link to ensure the orderly development of the modern apprenticeship pilot program. 


\section{CURRENT SituATION OF ENROLLMENT AND RECRUITMENT INTEGRATION UNDER THE MODERN} APPRENTICESHIP MODE

The ministry of education in China has given clear requirements in the modern apprenticeship pilot work in view of how to promote the enrollment and recruitment integration work under the modern apprenticeship system, that is, to coordinate the enrollment of secondary and higher vocational education, expand the autonomy of pilot institutions, combine needs of cooperative enterprises to jointly complete the selection and enrollment work of students (apprentices), and enroll students (apprentices) into the unified management of the college. Since 2015, 165 units have been selected for the first batch of modern apprenticeship pilot programs, and then the second and third batch. So far, a total of 562 units have been selected for the modern apprenticeship pilot program. With the launch of the modern apprenticeship pilot program, practical exploration has also been carried out on the integration of modern apprenticeship enrollment and recruitment. By consulting literature and visiting modern apprenticeship pilot unit, it is found that the integration work of modern apprenticeship enrollment and recruitment has been effectively promoted. It is mainly manifested in the following aspects [3]:

\section{A. Joint enrollment and recruitment of colleges and}

enterprises have realized the dual subjects of enrollment and recruitment.

The biggest difference between the modern and traditional apprenticeship enrollment and recruitment is the introduction of enterprises, which participate in the enrollment and recruitment work as a main body. In the process of enrollment and recruitment work, enterprises provide corresponding positions and recruitment plans according to their actual needs. After written test and interview selection of students (apprentices), the final admission list is determined. In order to effectively protect the rights of the three parties (colleges, enterprises and students), the admitted students (apprentices), enterprises and colleges will jointly sign a tripartite agreement on the cultivation of modern apprenticeship talents, which determines the specific positions, teaching contents, job subsidies and rights and interests of the apprentices. It has implemented the policy requirements of recruiting students' equals to recruiting employees and entering the college equals to entering the enterprise, clarified apprentices' dual status of employees and students, and promoted the standardization and institutionalization of modern apprenticeship training.

\section{B. Forms of enrollment and recruitment are diversified,} enriching the connotation of enrollment and recruitment integration under the mode of modern apprenticeship

With the expansion of the modern apprenticeship pilot program scope, the exploration of enrollment and recruitment is becoming more and deeper, and the form of enrollment and recruitment is diversified. From the current point of view, there are three main forms of enrollment and recruitment for modern apprenticeships: the first is the simultaneous enrollment and recruitment, that is, students can become preparatory employees of the enterprise through signing enterprise labor contract while being accepted by the college at the same time.
The second is to enroll students and then recruit employees, that is, after the enrollment is completed, enterprises then go to the college to recruit and select outstanding students to form a modern apprenticeship pilot class. The third is to recruit employees and then enroll students, that is, after the recruitment is completed; colleges then go to the enterprise to select outstanding and potential employees to carry out academic education.

\section{RESEARCH ON PROBLEMS AND CAUSES OF THE ENROLLMENT AND RECRUITMENT INTEGRATION UNDER THE MODE OF MODERN APPRENTICESHIP}

At present, in China, the modern apprenticeship pilot is in its infancy, and its forms, organizational process and system construction are still being explored. Therefore, in the process of modern apprenticeship pilot system, numerous new problems and new situations have emerged, which are mainly reflected in the following aspects [4-5]:

\section{A. The autonomy of enrollment and recruitment in the pilot units is limited}

Although the organization form of enrollment and recruitment is carried out independently by the college and enterprise, students (apprentices) enrollment plan, students' registration, professional qualification certificate and academic certificate still need to be managed in accordance with the requirements of higher authorities such as education, personnel, and examination centers. Due to the diversity of subjects involved in enrollment and recruitment and it is still in the pilot exploration stage, the standard effective and convenient operation process has not been formed, which affects the efficiency of enrollment and recruitment integration under the mode of modern apprenticeship. In addition, the current college entrance enrollment policy does not consider modern apprenticeship, so pilot units can only be solved through single recruitment. Since the single recruitment policy does not allow recruiting in-service employees in cross-provincial enterprises, and they must take college entrance examination, therefore, in a strict sense, the synchronization between enrollment and recruitment is difficult to implement. Enterprises can only select students after they are admitted to the college through single recruitment or general college entrance examination, which to some extent restricts the in-depth promotion of modern apprenticeship pilot work.

\section{B. Enterprises are not enthusiastic and the cooperation between colleges and enterprises is not deep.}

Exploring the reform of vocational education is the responsibility of higher vocational colleges. In addition to the strong support of the modern apprenticeship at the national level, colleges are enthusiastic to participate in the modern apprenticeship program. However, the main consideration of enterprises is profit. In the modern apprenticeship system, enterprises have to pay a certain cost for the training of students and bear certain risks, in addition, the government does not give enough support for enterprises, which makes it difficult for enterprises to synchronize with colleges. Therefore, modern college-enterprise cooperation on apprenticeship system presents an embarrassing phenomenon of enthusiastic enterprise and indifferent enterprise, which seriously affects the 
depth and sustainability of college-enterprise cooperation. The main reason is that some enterprises pay too much attention to short-term interests, and they do not have a deep understanding of the long-term impact of such talent training methods. In addition, the cost of modern academic talents training is high, but the rate of success is lower, and the rate of brain drain after graduation is high, which leads to increased risks for enterprises. Therefore, some enterprises participating in the modern apprenticeship pilot system are only on the surface and have not yet entered the deep-level college-enterprise cooperation.

\section{Higher vocational colleges themselves do not have a deep understanding of the modern apprenticeship system, which increases the difficulty of implementation.}

Although China advocates the exploration and promotion of modern apprenticeship system throughout the country, it does not mean that every major in higher vocational colleges can adopt modern apprenticeship to train talents. Some higher vocational colleges blindly choose pilot majors in order to promote the modern apprenticeship pilot program, and enterprises are not interested in the pilot profession. Higher vocational colleges have to invite enterprises to participate through interpersonal relationship, but enterprises only offer some purely physical and unskilled posts to cope with this. As a result, students have to leave since they can learn nothing. This kind of modern apprenticeship exploration which is lack of deep understanding of the modern apprenticeship is obviously futile.

\section{Students and parents are not enthusiastic, which affects} the quality of enrollment and recruitment work for modern apprenticeships

The modern apprenticeship training mode is still a novelty for students and parents. Their understanding of education is fixed in the traditional training mode, that is, learning on campus, completing homework and obtaining a diploma. They have some misunderstandings about the combination of working and studying in the modern apprenticeship system. They believe that the talent training mode of the modern apprenticeship system is separated from the essence of education. In addition, since the modern apprenticeship system is in its infancy, it lacks successful examples showing obvious advantages of the modern apprenticeship. Therefore, students are not really enthusiastic to participate in the modern apprenticeship program, which leads to the phenomenon that the number of applicants is less than that of enrollment plan in the process of enrolling modern apprenticeship pilot classes. Therefore, in order to promote the implementation of the modern apprenticeship project, pilot units have to reduce the threshold for enrollment, resulting in low quality of enrollment and recruitment.

\section{COUNTERMEASURES AND SUGGESTIONS FOR PROMOTING THE ENROLLMENT AND RECRUITMENT INTEGRATION UNDER THE MODE OF MODERN APPRENTICESHIP}

As a new form to cultivate vocational talents, modern apprenticeship has characteristics of diverse involved subjects (government, colleges, enterprises, students), extensive enrollment and recruitment objects and multiple evaluation methods compared with traditional recruitment. In the implementation of the modern apprenticeship pilot program, the most obvious problem is that involved subjects cannot form an effective synergy [6]. Therefore, in order to effectively promote the enrollment and recruitment integration work of modern apprenticeship, it is necessary to find the interests balance among the government, colleges, enterprises and students, so as to ensure the smooth progress of the enrollment and recruitment integration work of modern apprenticeship.

A. Decentralizing and implementing the autonomy of pilot units to enroll students and simplifying the recruitment process.

Superior educational departments such as education, personnel and examination centers should formulate supporting management methods for recruiting students, simplify recruitment procedures of modern apprenticeships, reduce the number of administrative examinations, and fully consider the actual situation of recruitment. They should also give more autonomy to pilot units in terms of enrollment plan, students registration, professional qualification certificate and academic certificate management, and at the same time explore the reform of single recruitment system, so as to include incumbent employees who meet certain conditions in the counterparts into the modern apprenticeship enrollment and let them enjoy the dual identity and treatment of apprenticeship.

\section{B. Seeking common interests between colleges and enterprises to promote the deep college-enterprise cooperation}

In the short run, enterprises may invest more than output in the modern apprenticeship, but the sustainable development of enterprises in the future cannot be separated from the support and guarantee of talents. Entrepreneurs generally believe that they must have their own talent reserves if they want their companies to be bigger and stronger. Therefore, it is necessary to seize the common goal of talent cultivation needs of enterprises and higher vocational colleges, and actively mobilize the enthusiasm and initiative of college-enterprise cooperation. If the two parties can fully combine their demands and jointly formulate personnel training systems, measures and programs that meet the needs of enterprises, then they can realize a win-win situation. At the same time, the government can mobilize the enthusiasm of enterprises through various incentive mechanisms and compensation mechanisms. Colleges should also strictly manage and give full play to the advantages of educational resources, methods and theories to enhance the quality of personnel training. Through this cooperative approach of mutual benefit, risk sharing and resource sharing, the enthusiasm of the two sides will be stimulated, and the deep cooperation between colleges and enterprises will be promoted to ensure the sustainable development of the modern academic system.

C. Deepening theoretical study of the modern apprenticeship system, setting up the pilot major reasonably, and selecting cooperative enterprises based on their merits

Higher vocational colleges should conscientiously and deeply understand the connotation and system framework of the modern apprenticeship system, grasp its essential 
characteristics, and combine their actual conditions to choose the modern apprenticeship pilot major and cooperative enterprises. The pilot major should meet market demands, and have characteristics of strong operational skills and high professional training requirements. In addition, they should fully consider whether the major construction has a certain preliminary basis, such as whether faculty resource is sufficient, whether basic training facility is perfect, and whether student training forms a scale. Choosing the pilot major correctly is the crucial basis for the follow-up work of modern apprenticeship. When choosing cooperative enterprises based on their merits, they should consider professional counterparts' situation, scale of the enterprise, reputation of the enterprise, enthusiasm for the modern apprenticeship system and planning of personnel training. Finally, the cooperative enterprises should be selected rationally through evaluation.

\section{Increasing the propaganda of modern apprenticeships and} vigorously promoting the results of the pilot.

Colleges should start from the immediate interests of students and parents to publicize advantages of modern apprenticeship system. Meanwhile, they should actively summarize the achievements of modern apprenticeship system, take successful cases as examples, and explain to students and parents that modern apprenticeship system can bring real help to students' growth, so as to eliminate students' doubts about modern apprenticeship system. At the same time, colleges should strictly follow the principle of selecting students based on their merits in the enrollment and recruitment work of modern apprenticeship system, and form a good atmosphere of being proud to enter the pilot class among students.

\section{SUMMARY}

Modern apprenticeship is an important exploration of vocational education reform and a mainstream mode of future vocational education in China. The enrollment and recruitment integration is the foundation of the modern apprenticeship system and the key link in the cultivation of modern apprenticeship talents. With the launch of the modern apprenticeship pilot program, pilot units closely focus on the requirements of recruiting students equals to recruiting employees, entering the college equals to entering the enterprise, graduation equals to employment, and college-enterprise joint training. They have also made positive exploration from the aspects of recruitment methods, recruitment organization, examination and admission. Some typical problems in the process of exploration, such as the limited autonomy of recruiting students in pilot units, the low enthusiasm of enterprises, the lack of understanding of the modern apprenticeship in higher vocational colleges, and the misunderstanding of modern apprenticeship by students and parents have been summarized and analyzed, and countermeasures have been put forward from the perspective of balanced interests among the government, colleges, enterprises and students, providing reference for the modern apprenticeship pilot work.

\section{REFERENCES}

[1] Alexander Salvisberg \& Stefan Sacchi. Labour Market Prospects of Swiss Career Entrants after Completion of Vocational Education and a Training [J]. European Societies 2014 (16):255-274.

[2] Minns C, Wallis P. Rules and reality: quantifying the practice of apprenticeship in early modern England [J]. Economic History Review, 2012(65):87-92

[3] XUE Li-feng, YE Hong-ying. Exploration and Practice of Implementing "Enrollment and Recruitment Integration" in Higher Vocational Colleges - Taking Higher Vocational Colleges in Hebei Province as an Example [J]. Journal of Hebei Radio \& TV University, 2019 (23):91-93. (In Chinese)

[4] LIQing. Analysis on the Practice Approach of Modern Apprenticeship with Students Recruitment Integrating into Employment-Taking School-enterprise Cooperation Model in Fujian Province as an Example [J]. Journal of Tianjin Vocational Institute, 2015 (24):47-51. (In Chinese)

[5] Yang Libo, Yan Lina.On Enlightenments of Swiss Two-year Apprenticeship Training to Modern Apprenticeship in China[J]. Vocational and Technical Education,2018 (39)74-79. (In Chinese)

[6] Fu Gai. Reflections on the Reform of Recruitment and Enrollment System Corresponding to Modern Apprenticeship [J]. Journal of Jinan Vocational College, 2016 (04):9-11. (In Chinese) 